\title{
MEDIA PEMBELAJARAN KOMPOSISI FOTO DIGITAL PADA SISWA KELAS XI PROGRAM KEAHLIAN MULTIMEDIA SMK MUHAMMADIYAH 1 LAMONGAN
}

\author{
Kurnia Yahya, S.Kom., M.Kom \\ Guru Produktif Multimedia SMK Muhammadiyah 1 Lamongan \\ Jl. Veteran No. 51 A Lamongan \\ E-mail: kurnia_yahya@yahoo.com
}

\begin{abstract}
Digital Photo Composition is one of the competencies that must be mastered by students in completing learning in Multimedia Vocational High School. Digital Photo Composition is a very important part in the world of graphic design. To master this competence requires a deep understanding. In the delivery of the material either theoretically or practicum of a teacher should really be able to attract students sympathy that students finally feel comfortable and motivated in learning. Interactive Media Learning DIGITAL PHOTOGRAPHY used to take Competency Standard Composition Digital Photos, In this learning media, learners will learn from knowing the parts of the camera to the process of photo editing. It consists of interactive content and includes animations, videos, text, photos and simulations. There is also a random evaluation for the answer as well as the scoring system at the end of the evaluation. This media is expected to be a learning material for the students mengasikkan mengasikkan and ultimately students can understand and able even without any learning in the classroom
\end{abstract}

Keywords: Composition, Photos, Digital, Media, Learning

\section{PENDAHULUAN}

Dalam Profesionalisme guru sangat menentukan keberhasilan belajar siswa. Menurut Hamalik (1990), profil kemampuan dasar guru mencakupi: (1) kemampuan menguasai bahan, (2) kemampuan mengelola program belajar mengajar, (3) kemampuan mengelola kelas, (4) kemampuan menggunakan media dan sumber, (5) kemampuan menguasai landasan pendidikan, (6) kemampuan menilai prestasi belajar siswa, (7) kemampuan mengelola interaksi belajar mengajar, dan sebagainya.

Bagi guru yang mengajar Pelajaran Produktif Multimedia, kemampuan di atas belumlah cukup. Guru dituntut pula memiliki keterampilan, sebab guru sering dijadikan contoh bagi para siswanya. Keberhasilan sorang guru dalam mengajar akan terlihat dari tercapainya target kurikulum yang telah ditentukan. Tercapainya target kurikulum bisa dilihat dari evaluasi yang diberikan kepada siswa. Apabila evaluasi bisa diselesaikan siswa dengan baik, berarti target kurikulum tercapai. Dengan kata lain guru dikatakan berhasil bila pembelajaran yang diberikan bisa dikuasai anak. Tingkat penguasaan siswa terhadap materi pelajaran dapat dilihat dari keaktifan siswa dalam menjawab pertanyaan atau memberi tanggapan.

Keberhasilan siswa juga dilihat melalui nilai yang diperoleh. Ternyata pada ulangan harian yang dilaksanakan oleh guru khususnya tentang kompetensi dasar di ranah pengetahuan memperlihatkan nilai-nilai yang diperoleh siswa rendah. Dari 20 siswa yang mendapat nilai $70 \%$ ke atas hanya 4 siswa, sedangkan 16 siswa masih $60 \%$ ke bawah.

Tujuandari penelitian ini yaitu: 1) membantu Guru dalam menagani hambatan atau kendala dalam menyajikan materi pelajaran Komposisi Foto Digital. 2) Mendapatkan suatu cara atau metode yang dapat meningkatkan pemahaman siswa terhadap materi pembelajaran tentang Komposisi Foto Digital.

Menurut McCornick multimedia secara umum merupakan kombinasi tiga elemen, yaitu suara, gambar dan teks. Menurut Turban, dkk multimedia adalah kombinasi dari paling sedikit dua media input atau output dari data, media ini berupa audio (suara, musik), animasi, video, teks, grafik, dan gambar.

Menurut Robin dan Linda multimedia merupakan alat yang dapat menciptakan presentasi yang dinamis dan interaktif yang mengkombinasikan teks, grafik, animasi, audio, dan gambar video. Definisi lain dari multimedia 
yaitu dengan menempatkan dalam konteks seperti yang dilakukan Hofstetter, multimedia adalah pemanfaatan computer untuk membuat dan menggabungkan teks, grafik, audio, gambar bergerak (video dan animasi) dengan menggabungkan link dan tools yang memungkinkan navigasi, berinteraksi, berkreasi, dan berkomunikasi.

CD Interaktif terdiri dari kata $\mathrm{CD}$ dan Interaktif. $C D$ adalah media penyimpanan data yang merupakan singkatan dari Compact Disc. Sedangkan Interaktif adalah komunikasi 2 arah atau disebut juga dialog. 2 arah maksudnya adalah kita ikut aktif untuk menentukan jalannya materi, seperti pada game dan website. Jika hanya 1 arah / monolog, kita hanya dapat menonton jalannya materi dari awal sampai akhir seperti menonton film atau mendengar musik. Jika diartikan secara sederhana, CD Interaktif adalah Materi yang bisa diakses sesuai keinginan pengguna dalam media $C D$.

Komposisi Foto Digital membahas beberapa hal penting yang perlu diketahui agar siswa berkompeten untuk memahami software pengolah gambar raster, mengedit, menggabungkan, memberi efek-efek beserta komponen-komponennya secara efektif, efisien dan aman. Terdapat tiga kompetensi dasar dalam standar kompetensi Menggabungkan fotografi digital ke dalam sajian multimedia

a. Menggunakan kamera digital.

b. Menggabungkan foto digital ke dalam rangkaian multimedia.

c. Menciptakan susunan karya seni foto digital

\section{METODE PENELITIAN}

Penelitian ini merupakan penelitian pengembangan yang mengacu pada model pengembangan yang terdiri dari tahapan pengembangan yaitu Define, Design, and Develop, yang diadaptasi dari Thiagarajan, Semmel dan Semmel dalam Ibrahim,(2001). Model ini dipilih karena tahapan pengembangannya tersusun secara sistematis sehingga mempermudah peneliti dalam pelaksanaan untuk masing-masing langkah pengembangan dapat terkontrol dengan baik.

Penelitian ini dimaksudkan untuk mengembangkan media pembelajaran CD interaktif sebagai produk penelitian. Untuk mengembangkan produk, rancangan penelitian yang digunakan adalah model pengembangan dari Thiagarajan yang terdiri dari tahap define (pendefinisian), tahap design (Perancangan) dan tahap develop (Pengembangan).

Konten media pembelajaran mengacu pada Silabus dan Rencana Pelaksanaan Pembelajaran pada Mata Pelajaran Komposisi Foto Digital pada Kelas XI Multimedia yang sesuai dari Kompetensi Inti dan Kompetensi Dasar (KIKD) Kurikulum 2013 edisi tahun 2013. KI-KD yang digunakan sebagai konten memuat :

1) Memahami prosedur pengoperasian kamera digital.

2) Menyajikan hasil analisis pengamatan terhadap tombol-tombol dan pengaturan kamera digital

3) Memahami ukuran bidang pandang pengambilan gambar.

4) Menyajikan gambar dengan variasi bidang pandang.

5) Memahami pengambilan gambar dengan teknik zoom dan panning.

6) Menyajikan gambar dengan teknik zoom dan panning.

Pada perancangan tampilan terdiri dari :

a) Halaman Intro

b) Halaman Kompetensi Dasar

c) Halaman Materi Pokok

d) Halaman Quiz

e) Halaman Tentang

Pada halaman utama terdiri dari 4 Kompetensi Dasar yang diletakkan secara statis di kiri halaman. Rancangan tampilan lebih detil dapat dilihat pada Gambar 1.

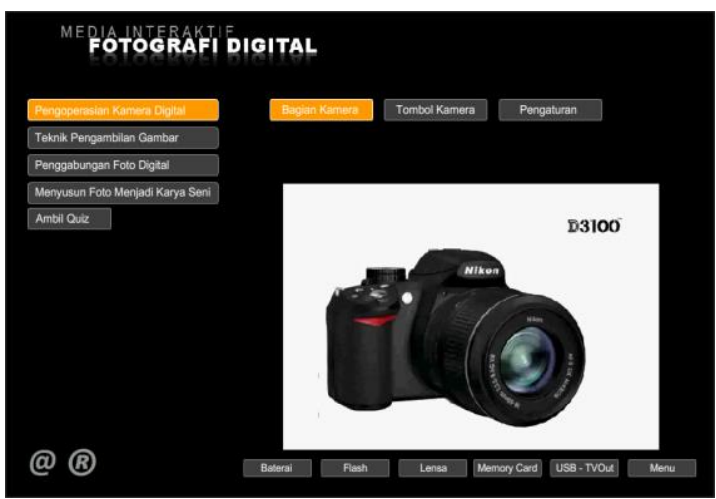

Gambar 1 Tampilan Utama

Sedangkan untuk materi pokok merupakan sub-menu daripada kompetensi Dasar. Untuk Halaman Kuis diletakkan sesuai dengan halaman materi pokok, kuis ini memiliki sistem penilaian secara langsung. Halaman kuis ditunjukkan pada Gambar 2. 


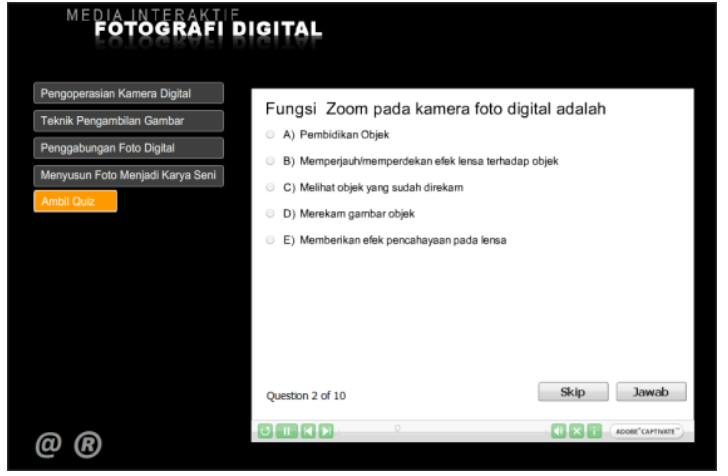

Gambar 2 Tampilan Kuis

Halaman tentang berisi nama pembuat media dan referensi dari media. Metode Uji Coba Produk

- Metode Dokumentasi. Metode ini digunakan untuk memperoleh data:

$>$ Daftar nama siswa kelas XI Multimedia semester II SMK Muhammadiyah 1 Lamongan yang dipilih menjadi sampel penelitian.

Daftar nilai Ulangan Harian siswa kelas XI Multimedia semester II SMK Muhammadiyah 1 Lamongan untuk kompetensi Komposisi Foto Digital.

- Metode Angket. Metode ini digunakan untuk memperoleh data penggunaan $\mathrm{CD}$ Interaktif pada siswa kelas XI Multimedia semester II SMK Muhammadiyah 1 Lamongan. Bentuk angket yang digunakan adalah bentuk yang sering digunakan dalam kegiatan penelitian, dengan ciri bahwa interval skalanya sama, mudah mengembangkannya, variasi yang dicapai lebih luas sehingga sering disebut dengan skala likert.

Hasil pengisian angket diberi skor dengan cara sebagai berikut, untuk pernyataan positif, bila siswa menjawab pada jawaban sangat, maka siswa diberi skor penilaian 4 , bila siswa menjawab dengan jawaban sesuai maka skornya 3 , bila siswa menjawab dengan jawaban cukup maka diberi skor 2, bila siswa menjawab dengan jawaban tidak maka diberi skor 1. Untuk pernyataan negative maka pemberian skor dengan cara kebalikannya. (Ruseffendi, 1994 :120).

\section{HASIL DAN PEMBAHASAN}

Didalam pelaksanaan penelitian diambil sampling 2 kelas multimedia, yaitu kelas A dan Kelas B. Keduanya diberikan materi yang sama dalam kelas namun kelas A diberi CD Interaktif. Hasilnya kelas A memiliki nilai ratarata yang lebih tinggi daripada kelas B yaitu sebesar 84. Sedangkan rata-rata nilai kelas B yaitu 79. Data ini ditunjukkan pada Tabel 1.

Tabel 1 Rata-rata Nilai Siswa

\begin{tabular}{ccccc}
\hline No & Kelas & $\begin{array}{c}\text { Jumlah } \\
\text { Siswa }\end{array}$ & $\begin{array}{c}\text { Jumlah } \\
\text { Nilai }\end{array}$ & $\begin{array}{c}\text { Rata-Rata } \\
\text { Nilai }\end{array}$ \\
\hline 1 & $\begin{array}{c}\text { Kelas } \\
\text { A }\end{array}$ & 37 & 3096 & 84 \\
\hline 2 & $\begin{array}{c}\text { Kelas } \\
\text { B }\end{array}$ & 33 & 2616 & 79 \\
\hline
\end{tabular}

Sedangkan hubungan antara CD Interaktif dengan nilai siswa kelas A menyatakan bahwa Terdapat hubungan antara CD Interaktif dengan Nilai / Kemampuan siswa Kelas A seperti yang ditunjukkan dalam Analisis Chi-Square dibawah ini

\begin{tabular}{|r|r|r|r|r|r|r||}
\hline \multicolumn{7}{|c|}{ Case Processing Summary } \\
\hline \multirow{3}{*}{} & \multicolumn{7}{|c|}{ Cases } \\
\cline { 2 - 7 } & \multicolumn{2}{|c|}{ Valid } & \multicolumn{2}{c|}{ Missing } & \multicolumn{2}{c|}{ Total } \\
\cline { 2 - 8 } & $N$ & Percent & $N$ & Percent & $N$ & Percent \\
\hline $\mathrm{J} \mathrm{X}^{*} \mathrm{UH}$ & 37 & $100.0 \%$ & 0 & $.0 \%$ & 37 & $100.0 \%$ \\
\hline \hline
\end{tabular}

Gamabr 3 Hasil analisis Chi-Square

$\mathrm{JX}$ * UH Crosstabulation

\begin{tabular}{|c|c|c|c|c|c|c|c|c|}
\hline & & \multicolumn{6}{|c|}{ UH } & \multirow[b]{2}{*}{ Total } \\
\hline & & 72.00 & 76.00 & 80.00 & 84.00 & 88.00 & 92.00 & \\
\hline \multirow[t]{10}{*}{$\sqrt{J x}$} & .45 & 2 & 0 & 0 & 0 & 0 & 0 & 2 \\
\hline & .50 & 0 & 1 & 0 & 0 & 0 & 0 & 1 \\
\hline & .55 & 0 & 1 & 0 & 0 & 0 & 0 & 1 \\
\hline & .59 & 0 & 3 & 1 & 1 & 0 & 0 & 5 \\
\hline & .64 & 0 & 1 & 0 & 0 & 0 & 0 & 1 \\
\hline & .73 & 0 & 0 & 2 & 3 & 1 & 0 & 6 \\
\hline & .77 & 0 & 0 & 0 & 4 & 0 & 1 & 5 \\
\hline & .82 & 0 & 0 & 1 & 5 & 4 & 3 & 13 \\
\hline & .86 & 0 & 0 & 0 & 0 & 0 & 1 & 1 \\
\hline & .91 & 0 & 0 & 0 & 0 & 0 & 2 & 2 \\
\hline \multicolumn{2}{|c|}{ Total } & 2 & 6 & 4 & 13 & 5 & 7 & 37 \\
\hline
\end{tabular}

Gamabr 3 Hasil analisis Chi-Square

Hasil pengujian linearitas $\mathrm{X} 1$ dengan $\mathrm{Y}$, didapatkan nilai $\mathrm{p}$ sebesar 0,919 dan nilai $\mathrm{F}$ sebesar 0,642. Sebagaimana kriteria di atas bahwa jika $\mathrm{p}>0,05$ maka dinyatakan berkorelasi linear. Dengan nilai $p$ yang di dapatkan sebesar 0,919>0,05 maka dapat dinyatakan $\mathrm{X} 1$ dengan $\mathrm{Y}$ berkorelasi linear. Sehingga dapat disimpulkan bahwa terdapat hubungan antara masing-masing variabel bebas 
dengan variabel terikat dalam bentuk linear (hubungan garis lurus).

Chi-Square Tests
\begin{tabular}{|l|r|r|r|}
\hline \multicolumn{1}{|c|}{ Value } & \multicolumn{1}{c|}{ df } & $\begin{array}{c}\text { Asymp. Sig. } \\
\text { (2-sided) }\end{array}$ \\
\hline Pearson Chi-Square & $88.662^{\mathrm{a}}$ & 45 & .000 \\
Likelihood Ratio & 62.262 & 45 & .045 \\
Linear-by-Linear & 25.822 & 1 & .000 \\
Association & 37 & & \\
N of Valid Cases & & \\
\hline
\end{tabular}
a. 60 cells (100.0\%) have expected count less than 5. The
minimum expected count is .05.

Gamabr 3 Hasil analisis

Ho: Tidak ada hubungan antara baris dan kolom, atau antara Media Pembelajaran dengan Nilai Siswa tersebut.

Hi: Ada hubungan antara baris dan kolom, atau antara Media Pembelajaran dengan Nilai Siswa.

Pengambilan Keputusan. Dasar Pengambilan Keputusan Berdasarkan perbandingan ChiSquare hitung dengan Chi-Square tabel:

* Jika Chi-Square Hitung < Chi-Square Tabel maka Ho diterima.

* Jika Chi-Square Hitung > Chi-Square Tabel maka Ho ditolak.

Chi-Square Hitung -lihat pada output SPSS bagian PEARSON CHISQUARE- adalah 88,662 .

Berdasarkan Probabilitas (signifikansi):

$>$ Jika probabilitas $>0,05$, maka $\mathrm{Ho}$ diterima

$>$ Jika probabilitas $<0,05$, maka $\mathrm{Ho}$ ditolak

Keputusan:

Terlihat bahwa pada kolom Asymp. Sig adalah 0,045 , atau probabilitas diatas 0,05 $(0,021<0,05)$. Maka Ho diterima

\section{KESIMPULAN}

Dari hasil perbaikan yang telah dilaksanakan dapt ditarik beberapa kesimpulan sebagai berikut:

1. CD Interaktif dapat mengisi pelajaran yang hilang dikelas sehingga nilai ratarata lebih tinggi dari pada yang tidak menggunakan CD Interaktif.
2. Terdapat hubungan antara CD Interaktif dengan Nilai / Kemampuan siswa.

3. Siswa memerlukan motivasi dalam belajar, baik dari dalam dirinya sendiri maupun dari luar dirinya

\section{REFERENSI}

[1] Depdiknas, 2006. Kurikulum Tingkat Satuan Pendidikan. Jakarta.

[2] Brown, H. Doulas. 1994. Teaching by Principles: An Interactive Approach to Language Pedagogy. New Jersey: Prenice Hail Regent

[3] Lado, Robert, 1989. Language Teaching: A Scientific Approsch. New Delhi: Tata McGraw-Hill.

[4] Littewood, William, 1981. Communicative Language Teaching: An Introduction. New York: Cambridge University Press.

[5] Ruseffendi, E.T. (1998). Statistik Dasar untuk Penelitian Pendidikan. Bandung: IKIP Bandung

[6] Thiagarajan, S., Semmel, D. S \& Semmel, M. I. 1974. Instructional Development for Training Teachers of Expectional Children. Minneapolis, Minnesota: Leadership Training Institute/Special Education, University of Minnesota.

[7] Nyoman Merdhana, 2002. Tindakan Kelas sebagi Salah Satu Alternatif Pengajaran Menyimak dalam PBIPA. Jakarta:

http://www.ialf.edu/kipbipa/abstracts/nyo manmerdhana.htm.

[8] Wardani, I.G.A.K., Wihardi, Kuswaya, Nasution Noehi, 2002. Penelitian Tindakan Kelas. Jakarta, Universitas Terbuka.

[9] Wardani, I.G.A.K., Siti Julaeha, M.A. Pemantapan Kemampuan Profesional. Jakarta, Universitas Terbuka.

www.edukasi.net

www.nikonusa.com

www.camerasim.com 